\title{
ANALISIS PENGELOLAAN AKUNTANSI ASET PADA BADAN KESATUAN BANGSA DAN POLITIK PROVINSI SULAWESI UTARA
}

\author{
Lovenhia Claudya Tani ${ }^{1}$, Hendrik Manossoh ${ }^{2}$, Heince Rudy Nicky Wokas ${ }^{3}$ \\ 1,2,3 Jurusan Akuntansi, Fakultas Ekonomi dan Bisnis, Universitas Sam Ratulangi, Jl. Kampus Bahu, Manado, \\ Indonesia, 95115 \\ E-mail: lovenhiatani@gmail.com
}

\begin{abstract}
Asset accounting is one of the most important components in order to achieve good governance. Asset accounting has a management that must comply with the applicable rules. The purpose of this research is to know how to manage the asset accounting at The National and Politics Board of North Sulawesi Province by implementing the accrual based government accounting standard, using the analysis method. Results of the study of The National and Politics Board of North Sulawesi Province demonstrate the implementation of the management process of asset goods accounting on The National and Politics Board of North Sulawesi Province on every sub system has not been effectively affected overall. Based on the results the authors give advice on the unity of the nation and politics to continue to maintain or improve the performance in carrying out the mandate of law.
\end{abstract}

Keywords: analysis; asset; government accounting standards

\section{PENDAHULUAN}

Dalam sistem akuntansi pemerintahan ditetapkan entitas pelaporan dan entitas akuntansi yang menyelenggarakan sistem akuntansi pemerintahan daerah. Akuntansi aset adalah sumber daya ekonomi yang dikuasai dan dimiliki oleh pemerintah sebagai akibat dari peristiwa masa lalu dan dari mana manfaat ekonomi dan sosial di mana masa depan diharapkan dapat diperoleh, baik oleh pemerintah, masyarakat, serta dapat diukur dalam satuan uang, termasuk sumber daya non keuangan yang diperlukan untuk penyediaan jasa bagi masyarakat umum dan sumber-sumber daya yang dipelihara karena alasan sejarah dan budaya.

Seiring dengan reformasi di bidang keuangan negara, maka perlu dilakukan perubahan-perubahan di berbagai bidang untuk mendukung agar reformasi di bidang keuangan negara dapat berjalan dengan baik. Salah satu perubahan yang signifikan adalah perubahan di bidang akuntansi pemerintahan karena melalui proses akuntansi dihasilkan informasi keuangan yang tersedia bagi berbagai pihak untuk digunakan sesuai dengan tujuan masing-masing. Informasi inilah yang akan menjadi alat pertanggungjawaban kepada pihak-pihak yang membutuhkan tersebut.

Sistem akuntansi daerah secara garis besar terdiri atas empat prosedur akuntansi, yaitu: prosedur akuntansi penerimaan kas, pengeluaran kas, selain kas, dan aset. Dengan standar pengelolaan akuntansi yang baik maka keberadaan aset yang dimiliki pemerintah dalam hal ini Badan Kesatuan Bangsa dan Politik Provinsi Sulawesi Utara akan lebih tertata dengan baik, dan dapat mengetahui bagaimana perkembangan yang terjadi terhadap aset-aset yang dimiliki.

\section{TINJAUAN PUSTAKA}

Menurut Bahri (2016:2), akuntansi adalah seni pencatatan, penggolongan, pengiktisaran, dan pelaporan atas suatu transaksi dengan cara sedemikian rupa, sistematis dari segi isi, dan berdasarkan standar yang diakui umum. Menurut Sadeli (2015:2), akuntansi 
digunakan untuk mencatat, meringkas, melaporkan, menginterpretasikan data dasar ekonomi untuk kepentingan perorangan, pengusaha, pemerintah, dan anggota masyarakat lainnya. Sedangkan menurut Hery (2016:2), akuntansi adalah sebuah sistem informasi yang memberikan laporan kepada para pengguna informasi akuntansi atau kepada pihak-pihak yang memiliki kepentingan terhadap hasil kinerja dan kondisi keuangan perusahaan, akuntansi juga sering dianggap sebagai bahasa bisnis, dimana informasi bisnis dikomunikasikan kepada stakeholders melalui laporan akuntansi. Peraturan Pemerintah nomor 71 Tahun 2010 akuntansi adalah proses identifikasi, pencatatan, pengukuran, pengklasifikasian, pengikhtisaran transaksi dan kejadian keuangan, penyajian laporan serta penginterpretasian atas hasilnya. Menurut Suwardjono (2014:10), akuntansi dideskripsikan sebagai seperangkat alat yang mempelajari implementasi penyedia jasa berupa laporan keuangan kuantitatif bagian organisasi dalam suatu lingkup negara tertentu dengan cara penyajian informasi tersebut kepada kelompok yang berkepentingan untuk dijadikan alasan dalam pengambilan keputusan ekonomi. Menurut Sumarsan (2013:1), akuntansi merupakan sebuah seni untuk mengumpulkan, mengidentifikasikan, mengklasifikasikan, mencatat transaksi dan juga kejadian yang berkaitan dengan keuangan. Sehingga mampu menghasilkan informasi yang berguna dan kemudian menyajikannya dalam bentuk laporan keuangan yang bisa dipakai oleh pihak-pihak yang berkepentingan. Akuntansi adalah sistem informasi dan pengukuran yang mengidentfikasi, mencatat dan mengkomunikasikan informasi yang relevan, dapat diandalkan, dan dapat dibandingkan tentang kegiatan bisnis organisasi (Wild et al. 2014:3). Menurut Sucipto (2014:1), akuntansi (accounting) adalah proses tiga aktivitas: identifikasi, pencatatan, dan komunikasi (identifying, recording, and communicating) peristiwa ekonomi sebuah organisasi (bisnis dan non bisnis) bagi pengguna informasi. Menurut Kartikahadi (2016:3), akuntansi adalah suatu sistem informasi keuangan, yang bertujuan untuk menghasilkan dan melaporkan informasi yang relevan bagi berbagai pihak yang berkepentingan. Secara umum akuntansi dapat didefinisikan sebagai suatu sistem informasi yang berfungsi menyediakan informasi kuantitatif dari suatu unit organisasi atau kesatuan ekonomi yang ditunjukan kepada para pemakai sebagai dasar dalam pengambilan keputusan ekonomi. Akuntansi adalah seperangkat pengetahuan yang mempelajari perekayasaan dalam penyediaan jasa, yang berupa informasi keuangan dari suatu unit organisasi dan cara penyampaian (pelaporan) informasi tersebut kepada pihak yang berkepentingan untuk dijadikan dasar pengambilan keputusan ekonomi (Pura, 2013:4).

Pada hakekatnya akuntansi pemerintahan adalah aplikasi akuntansi di bidang keuangan negara (public finance), khususnya pada tahapan pelaksanaan anggaran (budget execution), termasuk yang ditimbulkannya, baik yang bersifat seketika maupun yang lebih permanen pada semua tingkatan dan unit pemerintahan, tuntutan transparansi dan akuntabilitas publik atas penggunanaan akuntansi dalam mencatan dan melaporkan kinerja pemerintahan (Dedi, 2012:1). Nordiawan (2012:4) menjelaskan akuntansi pemerintahan mengkhususkan dalam pencatatan dan pelaporan transaksi-transaksi yang terjadi di badan pemerintah. Akuntansi pemerintahan termasuk pula akuntansi lembaga-lembaga nonprofit atau institutional accounting, mengkhususkan pada masalah pencatatan dan pelaporan transaksi dari unit-unit pemerintah dan organisasi nonprofit lainnya, seperti: masjid, lembaga amal, yayasan, rumah sakit, dan lembaga-lembaga pendidikan (Sadeli, 2015:6). Menurut Halim (2012:3), akuntansi pemerintahan adalah suatu proses pengidentifikasian, pengukuran, pencatatan dan pelaporan transaksi ekonomi (keuangan) dari suatu organisasi atau etnis publik seperti pemerintah, LSM dan lain-lain yang dijadikan sebagai informasi dalam rangka mengambil keputusan ekonomi oleh pihak-pihak yang memerlukan.

Akuntansi sektor publik dapat diartikan sebagai aktivitas jasa yang terdiri dari mencatat, mengklasifikasikan, dan melaporkan kejadian atau transaksi ekonomi yang akhirnya menghasilkan suatu informasi keuangan yang akan dibutuhkan pihak-pihak tertentu 
untuk pengambilan keputusan, yang diterapkan pada pengelolaan dana publik di lembagalembaga tinggi negara dan departemen-departemen dibawahnya (Sujarweni 2015:1). Menurut Siregar (2015:3) akuntansi sektor publik merupakan aktivitas akuntansi yang dilakukan terhadap kejadian dan transaksi keuangan organisasi sektor publik. Akuntansi sektor publik dapat dinyatakan sebagai aktifitas akuntansi yang diterapkan pada pemerintahan, baik pemerintah pusat maupun pemerintah daerah. Menurut Nordiawan dan Hertianti (2010:4), organisasi sektor publik menjadi berbeda dengan ciri-ciri berikut: (a) dijalankan untuk tidak mencari keuntungan finansial, melainkan untuk mencapai suatu misi atau tujuan tertentu; (b) dimiliki secara kolektif oleh publik; (c) kepemilikan atas sumber daya tidak digambarkan dalam bentuk saham yang dapat diperjualbelikan; dan (d) keputusan-keputusan yang terkait kebijakan maupun operasi sering kali di dasarkan pada konsensus.

Menurut Halim (2014: 4), tujuan akuntansi sektor publik adalah: (1) akuntabilitas yang ada didalam pemerintahan, keuangan Negara yang dijalankan harus dapat dipertanggungjawabkan sebagaimana mestinya sesuai dengan peraturan dan amanat konstitusi; dan (2) manajerial menjalankan suatu perencanaan yang berkaitan dengan penyusunan APBN dan strategi pembangunan-pembangunan lainnya, agar dapat melakukan pelaksanaan kegiatan pembangunan dan pengendalian atas kegiatan yang dilakukan tersebut dalam rangka untuk mencapai ketaatan kepada peraturan perundang-undangan yang efisiensi, efektivitas, dan ekonomis.

Berdasarkan Peraturan Menteri Dalam Negeri Nomor 64 Tahun 2013 tentang Penerapan Standar Pemerintahan Berbasis Akrual pada Pemerintah Daerah, aset adalah sumber daya ekonomi yang dikuasai dan/atau dimiliki oleh pemerintah daerah sebagai akibat dari peristiwa masa lalu dan darimana manfaat ekonomi dan/atau sosial dimasa depan diharapkan dapat diperoleh, baik oleh pemerintah daerah maupun masyarakat serta dapat diukur dalam satuan uang, termasuk sumber daya nonkeuangan yang diperlukan untuk penyediaan jasa bagi masyarakat umum dan sumber-sumber daya yang dipelihara karena alasan sejarah dan budaya. Peraturan Pemerintah Nomor 27 Tahun 2014 tentang Pengelolaan Barang Milik Negara/Daerah (mencabut PP Nomor 6 Tahun 2006 dan PP Nomor 38 Tahun 2008) mengatur tentang pengelolaan aset pemerintah baik aset pemerintah pusat maupun asset pemerintah daerah, yang diberi nama aset adalah barang. Pengertian barang menurut Peraturan Presiden Nomor 54 Tahun 2010 tentang Pengelolaan Barang/jasa Pemerintah adalah setiap benda baik berwujud maupun tidak berwujud, bergerak maupun tidak bergerak, yang dapat diperdagangkan, dipakai, dipergunakan atau dimanfaatkan oleh pengguna barang. Menurut Peraturan Pemerintah Nomor 27 Tahun 2014 dan Peraturan Menteri Dalam Negeri Nomor 19 Tahun 2016 Barang Milik Daerah/Negara ini yang dimaksud dengan:

1. Barang milik negara adalah semua barang yang dibeli atau diperoleh atas beban APBN atau berasal dari perolehan lainnya yang sah.

2. Barang milik daerah adalah semua barang yang dibeli atau diperoleh atas beban APBD atau berasal dari perolehan lainnya yang sah.

Alfons et al. (2016) menunjukkan bahwa sistem dan prosedur akuntansi aset sudah sesuai dengan Permendagri Nomor 17 Tahun 2007. Kolinug et al. (2015) menunjukkan bahwa DPPKAD Kota Tomohon sebagai pembantu pengelola telah menerapkan 6 siklus dalam pengelolaan aset tetap. Dari 15 dokumen sumber yang diperlukan hanya ada 13 dokumen saja, sehingga pengelolaan aset tetap pada DPPKAD Kota Tomohon dengan Permendagri Nomor 17 Tahun 2007 belum sepernuhnya sesuai. Kumambouw et al. (2016) menunjukkan bahwa Dinas Kesehatan Provinsi Sulawesi Utara dalam menjalankan kegiatan akuntansinya berpedoman pada Kebijakan Akuntansi Pemerintahan yang sudah mengarah pada PSAP Nomor 07 tentang aset tetap. Tipan et al. (2016) menunjukkan bahwa penyusutan terhadap aset tetap Dinas PU belum sesuai dengan PSAP yang berlaku. 


\section{METODE PENELITIAN}

Jenis penelitian yang digunakan dalam penelitian ini bersifat deskriptif. Penelitian ini menggunakan data primer berupa data yang diperoleh langsung dari objek penelitian, sedangkan data sekunder yang digunakan adalah dari literatur-literatur, buku yang bersangkutan dengan judul penelitian, serta artikel yang dibuat oleh pihak ketiga dan mempunyai reverensi dengan penelitian ini. Teknik analisis data yang digunakan dalam penelitian ini yaitu analisis deskriptif. Metode pengumpulan data yang digunakan dalam penelitian ini adalah wawancara dan dokumentansi.

\section{HASIL PENELITIAN DAN PEMBAHASAN}

\subsection{Hasil penelitian}

Pengelolaan aset/barang milik daerah merupakan sistem yang digunakan untuk mencatat seluruh kegiatan pengelolaan aset/barang milik daerah. Peraturan Pemerintah Nomor 27 Tahun 2014 pengelolaan barang milik daerah, pelaksanaan pengelolaan aset/barang milik daerah Badan Kesatuan Bangsa dan Politik Provinsi Sulawesi Utara dilakukan melalui prosedur penetapan APBD untuk kemudian setiap SKPD menyusun Daftar Kebutuhan Barang Milik Daerah (DKBMD) dan ditetapkan oleh Kepala Daerah untuk pelaksanaan anggaran belanja tahunan. SKPD menjalankan tugasnya dalam pelaksanaan pengelolaan aset/barang milik daerah dan Badan Kesatuan Bangsa dan Politik Provinsi Sulawesi Utara menjalankan tugasnya dalam penyusunan pelaporan aset/barang milik daerah. Analisis dalam penelitian ini meliputi perencanaan kebutuhan dan penganggaran barang, pengadaan barang, penerimaan, penyimpanan dan penyaluran barang, penggunaan barang, penatausahaan barang, pemanfaatan barang, pengamanan dan pemeliharaan barang, penghapusan barang.

\subsection{Pembahasan}

1. Perencanaan Kebutuhan dan Penganggaran Barang

Perencanaan kebutuhan dan penganggaran barang Badan Kesatuan Bangsa dan Politik Provinsi Sulawesi Utara pengelolaan akuntansi asetnya sudah memadai atau sudah sesuai dengan landasan teori yang terkait. Badan Kesatuan Bangsa dan Politik Provinsi Sulawesi Utara meneliti dan menghimpun seluruh Daftar Kebutuhan Barang Milik Daerah (DKBMD) yang diajukan oleh setiap SKPD apakah itu sudah sesuai dengan kebutuhan masing-masing SKPD, setelah itu Badan Kesatuan Bangsa dan Politik Provinsi Sulawesi Utara menyampaikan kepada Kepala Daerah melalui pengelola untuk kemudian daftar kebutuhan barang milik daerah tersebut dijadikan pedoman pelaksanaan pengadaan.

2. Pengadaan Barang

Pengadaan barang/jasa Badan Kesatuan Bangsa dan Politik Provinsi Sulawesi Utara pengelolaan akuntansi asetnya sudah efektif atau sudah sesuai dengan landasan teori yang terkait. Badan Kesatuan Bangsa dan Politik Provinsi Sulawesi Utara sudah melakukan pemeriksaan secara spesifik terhadap pengadaan aset milik daerah.

3. Penerimaan, Penyimpanan dan Penyaluran Barang

Pelaksanaan penerimaan, penyimpanan dan penyaluran barang Badan Kesatuan Bangsa dan Politik Provinsi Sulawesi Utara pengelolaan akuntansi asetnya sudah efektif atau sudah sesuai dengan landasan teori yang terkait. Badan Kesatuan Bangsa dan Politik Provinsi Sulawesi Utara telah melaksanakan inventarisasi dan pencatatan terhadap barang yang diterima, serta barang yang disalurkan oleh kepala SKPD. Kendala yang dihadapi oleh Badan Kesatuan Bangsa dan Politik Provinsi Sulawesi Utara dalam melaksanakan pengelolaan aset barang milik daerah (penyimpanan) adalah tidak adanya gudang penyimpanan barang, sehingga tidak ada tempat penyimpanan barang-barang inventaris.

4. Penggunaan Barang 
Penggunaan aset/barang milik Badan Kesatuan Bangsa dan Politik Provinsi Sulawesi Utara pengelolaan akuntansi asetnya belum efektif atau belum sesuai dengan landasan teori yang terkait. Badan Kesatuan Bangsa dan Politik Provinsi Sulawesi Utara dalam pelaksanaannya belum melakukan pencatatan terhadap aset/barang milik daerah yang digunakan oleh masing-masing pengguna barang.

5. Penatausahaan Barang

Penatausahaan barang milik daerah Badan Kesatuan Bangsa dan Politik Provinsi Sulawesi Utara pengelolaan akuntansi asetnya sudah sesuai dengan landasan teori yang terkait, dimana Badan Kesatuan Bangsa dan Politik Provinsi Sulawesi Utara melakukan koordinasi dalam pencatatan dan pendaftaran barang milik daerah kedalam Daftar Barang Milik Daerah (DBMD), serta mengiventarisasikan barang dengan melakukan pencatatan data dari masing-masing SKPD serta dibuat rekapitulasinya.

6. Pemanfaatan Barang

Pelaksanaan pemanfaatan barang milik daerah Badan Kesatuan Bangsa dan Politik Provinsi Sulawesi pengelolaan akuntansi asetnya belum efektif atau belum sesuai dengan landasan teori yang terkait. Kelemahan Badan Kesatuan Bangsa dan Politik Provinsi Sulawesi Utara adalah kurang optimalnya pemanfaatan barang milik daerah.

7. Pengamanan dan Pemeliharaan Barang

Pelaksanaan pengamanan dan pemeliharaan aset/barang milik daerah Badan Kesatuan Bangsa dan Politik Provinsi Sulawesi Utara pengelolaan akuntansi asetnya belum efektif atau belum sesuai dengan landasan teori yang terkait. Kendala yang dihadapi Badan Kesatuan Bangsa dan Politik Provinsi Sulawesi Utara dalam melaksanakan pengelolaan aset barang milik daerah (pengamanan) adalah kurang optimalnya pengamanan secara fisik terhadap barang milik daerah karena tidak adanya gudang penyimpanan barang, dan belum adanya dana alokasi khusus untuk pemeliharaan barang milik daerah.

8. Penghapusan Barang

Pelaksanaan penghapusan barang milik daerah Badan Kesatuan Bangsa dan Politik Provinsi Sulawesi Utara pengelolaan akuntansi asetnya belum efektif atau belum sesuai dengan landasan teori yang terkait. Badan Kesatuan Bangsa dan Politik Provinsi Sulawesi Utara hanya melaksanakan tugasnya yakni melaksanakan pengusulan terhadap aset-aset daerah yang layak untuk dihapuskan, dan Badan Kesatuan Bangsa dan Politik Provinsi Sulawesi Utara belum melaksanakan tindakan penghapusan aset/ barang milik daerah.

\section{KESIMPULAN DAN SARAN}

\subsection{Kesimpulan}

Hasil penelitian ini menunjukkan pengelolaan akuntansi aset/barang milik daerah pada

Badan Kesatuan Bangsa dan Politik Provinsi Sulawesi Utara pada setiap subsistem belum terlalu efektif secara keseluruhan dikarenakan masih ada subsistem yang belum melaksanakan dengan baik seperti pada bagian pemanfaatan serta penyimpanan yang belum dikelola dengan baik sehingga ada barang yang hanya tersimpan dibagian penyimpanan dan tidak dimanfaatkan dengan maksimal padahal semakin lama barang tersebut tersimpan juga akan semakin mengurangi nilai ekonomi dari barang tersebut hingga tidak menutup kemungkinan barangbarang tersebut akan habis masa ekonominya tanpa dimanfaatkan sebagaimana fungsinya.

\subsection{Saran}

Saran atas penelitian ini adalah untuk meningkatkan pengelolaan akuntansi aset/barang milik daerah secara efektif pada setiap subsistem khususnya pada pengadaan, penyimpanan dan penyaluran, penggunaan, pemanfaatan, pengamanan dan pemeliharaan, dan penghapusan. Aset/barang milik daerah sebaiknya dilaksanakan sesuai Peraturan Pemerintah Nomor 27 Tahun 2014 tentang pedoman teknis pengelolaan barang milik daerah. 


\section{DAFTAR PUSTAKA}

Alfons, W. M. A., Sabijono, H., \& Runtu, T. (2016). Analisis sistem dan prosedur akuntansi aset di Dinas Perhubungan Kota Manado. Jurnal Berkala Ilmiah Efisiensi, 16(4), 1186-1195. http://ejournal.unsrat.ac.id/index.php/jbie/article/view/14322

Bahri, S. (2016). Pengantar akuntansi berdasarkan SAK ETAP dan IFRS. Yogyakarta: Penerbit Andi.

Dedi, N. (2012). Akuntansi sektor publik. Yogyakarta: Pustaka Baru Press.

Halim, A. (2012). Akuntansi sektor publik: Akuntansi keuangan daerah, Edisi 4. Jakarta: Salemba Empat.

Halim, A. (2014). Akuntansi sektor publik: Akuntansi keuangan daerah, Edisi 4. Jakarta: Salemba Empat.

Hery. (2016). Akuntansi: Aktiva, utang dan modal, Edisi 2. Yogyakarta: Gava Media.

Kartikahadi, H. (2016). Akuntansi keuangan berdasarkan SAK berbasis IFRS, Edisi 2 Buku 1. Jakarta: Ikatan Akuntan Indonesia.

Kumambouw, L. N., Saerang, D. P. E., \& Pusung, R. (2016). Evaluasi penerapan akuntansi aset pada Dinas Kesehatan Provinsi Sulawesi Utara. Jurnal Berkala Ilmiah Efisiensi, 16(4), 1098-1109. http://ejournal.unsrat.ac.id/index.php/jbie/article/view/14312

Kolinug, M. S., Ilat, V., \& Pinatik, S. (2015). Analisis pengelolaan aset tetap pada Dinas Pendapatan Pengelolaan Keuangan dan Aset Daerah Kota Tomohon. Jurnal EMBA: Jurnal Riset Ekonomi, Manajemen, Bisnis dan Akuntansi, 3(1), 818-830. http://ejournal.unsrat.ac.id/index.php/emba/article/view/7556

Nordiawan, D. (2012). Akuntansi Sektor Publik. Jakarta: Salemba Empat.

Nordiawan, D., \& Hertianti, A. (2010). Akuntansi sektor publik, Edisi 2. Jakarta: Salemba Empat.

Peraturan Menteri Dalam Negeri Nomor 64 Tahun 2013 tentang Penerapan Standar Pemerintahan Berbasis Akrual pada Pemerintah Daerah.

Peraturan Pemerintah Republik Indonesia Nomor 27 Tahun 2014 tentang Pengelolaan Barang Milik Negara/Daerah.

Peraturan Pemerintah Republik Indonesia Nomor 71 Tahun 2010 tentang Standar Akuntansi Pemerintahan.

Peraturan Presiden Nomor 54 Tahun 2010 tentang Pengelolaan Barang/Jasa Pemerintah.

Pura, R. (2013). Pengantar akuntansi 1: Pendekatan siklus akuntansi. Jakarta: Erlangga.

Sadeli, L. M. (2015). Dasar-dasar Akuntansi. Jakarta: Penerbit Bumi Aksara.

Siregar, B. (2015). Akuntansi sektor publik (akuntansi keuangan daerah berbasis akrual), Edisi Kedua. Yogyakarta: UPP STIM YKPN.

Sucipto, T. (2014). Pengantar akuntansi dan keuangan bidang keahlian bisnis dan manajemen. Bogor: Yudhistira.

Sujarweni, V. W. (2015). Akuntansi sektor publik.Yogyakarta: Pustaka Baru Press.

Sumarsan, T. (2013). Perpajakan Indonesia, Edisi 4. Jakarta: PT.Indeks.

Suwardjono. (2014). Teori akuntansi: Perekayasaan pelaporan keuangan, Edisi 3. Yogyakarta: Badan Penerbitan Fakultas Ekonomi.

Tipan, A., Saerang, D. P. E., \& Lambey, R. (2016). Analisis perlakuan akuntansi aset tetap pada Dinas Pekerjaan Umum (PU) Provinsi Sulawesi Utara. Going Concern: Jurnal Riset Akuntansi, 11(1), 57-65. https://doi.org/10.32400/gc.11.1.10558.2016

Wild, J. J., Shaw, K. W., \& Chiappetta, B. (2014). Financial accounting information for decisions is an asian adaption of fundamental accounting, 20th Edition. Singapore: McGraw-Hill Education. 